\title{
Invasive Melastomataceae in Seychelles
}

\author{
Justin Gerlach
}

\begin{abstract}
The Seychelles are the only high oceanic islands of granitic origin and their native vegetation is thus of considerable botanical interest. In the nineteenth and early twentieth centuries widespread clearance for coconut and cinnamon plantations resulted in native forest being confined mainly to montane areas. Cinnamon has proved to be very invasive in natural forest and a number of other introduced plant species have also been recognized as problematic for some time. Recent studies have revealed that two more introduced plant species - Memecylon floribunda and Clidemia hirta - are significant new threats to native vegetation on Mahe and Silhouette, respectively.
\end{abstract}

The natural vegetation of Seychelles comprises a variety of habitat types, with moist upland forests predominating. There are also areas of exposed rock where the selective pressures of wind and high insolation are strong, resulting in the juxtaposition of a spectrum of hygrophilic and xerophytic taxa. Because the islands are the only high oceanic islands of granitic origin, the composition of the vegetation is of considerable botanical interest. With a relatively short history of human habitation the forests of Seychelles are relatively intact compared with those of the other islands of the western Indian Ocean.

Forest clearance in the nineteenth and early twentieth centuries has resulted in a large proportion of the forest habitats of Seychelles being dominated by introduced plants. The most obvious replacement of native vegetation occurred with the spread of coconut Cocos nucifera and cinnamon Cinnamomum verum plantations. These are virtually all abandoned now and represent a mix of introduced weeds and some regenerating indigenous species. Despite this, large areas of mainly natural habitat survive. These are generally remnants of montane forest where establishing plantations proved impractical.

Although existing remnants of natural forest are protected by the geographical factors that prevented their being replaced by commercially valuable plantation species, they are threatened by a gradual invasion of intro- duced plants. Of the invasive species cinnamon has long been recognized as a problematic invader, reports of vegetation replacement involving this species dating back to 1869 at least (Nevill, 1869). The threats posed by forest invasion of cinnamon, and also other introdcued weed species, such as Chrysobalanus icaco, Dicranopteris linearis and, very locally, Ananas comosus and Rangoon creeper Quisqualis indica, have been discussed in existing literature (Nevill, 1869; Procter, 1984; Friedmann, 1991), but there have been no quantitative studies of the habitats under threat.

Quantitative studies of the vegetation and invertebrate abundance of the habitats of Seychelles started recently have identified two introduced species of Melastomataceae that are contributing to the familiar pattern of vegetation replacement. The current distributions of these species, Clidemia hirta and Memecylon floribundum, in the islands are outlined below and the ecological consequences of their spread discussed based on data collected by the author in 1990 and 1991. At the time of writing only limited data are available for analysis but it is worth recording the early stages of the invasion by these two species.

\section{Memecylon floribundum}

Memecylon floribundum is a South East Asian species, first recorded from Java. It has not 


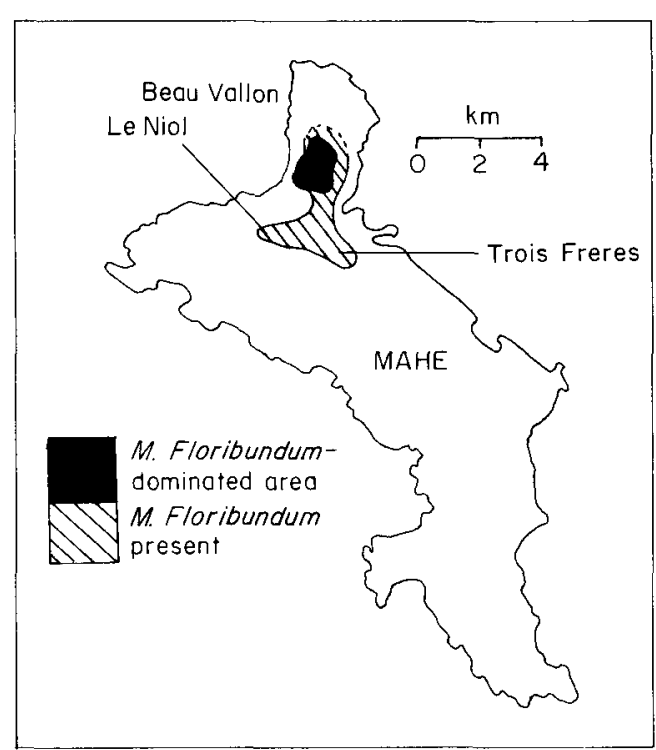

Figure 1. Location of Memecylon floribundumdominated habitat on Mahe by July 1991. Distributions based on field surveys. previously been recorded as a significant invader in Seychelles, although herbarium specimens collected by P. R. Dupont record its presence on Mahe since 1931 (Robertson, 1989). It also does not appear to have been reported as a significant weed in other areas. Consequently its true rate of spread is not known. At present it is recorded from Mahe only, where it occurs in the north of the island (Figure 1). An area of approximately $3 \mathrm{sq} \mathrm{km}$ is dominated by this species, from sea level to $400 \mathrm{~m}$ altitude. In this area it reaches a density of 7.5 plants over $2 \mathrm{~m}$ high per sq $\mathrm{m}$ (calculated as the average of eight randomly positioned $5 \times 5 \mathrm{~m}$ quadrats covering $200 \mathrm{sq} \mathrm{m}$ above Beau Vallon). Its dense canopy blocks out virtually all light. Where there are gaps in the canopy the ground is covered with $M$. floribundum seedlings. The only other seedlings recorded were those of cinnamon and jak fruit Artocarpus heterophyllus.

In other areas $M$. floribundum is abundant, but does not dominate the vegetation due to a
Table 1. Numbers of individuals of tree species above $2 \mathrm{~m}$ in height recorded in specific habitats

\begin{tabular}{|c|c|c|c|}
\hline Species & $\begin{array}{l}\text { Beau Vallon } \\
200 \mathrm{sq} \mathrm{m}\end{array}$ & $\begin{array}{l}\text { Trois Freres } \\
250 \mathrm{sq} \mathrm{m}\end{array}$ & $\begin{array}{l}\text { Le Niol } \\
175 \mathrm{sq} \mathrm{m}\end{array}$ \\
\hline \multicolumn{4}{|l|}{ Introduced } \\
\hline Albizia lebbeck & & 4 & \\
\hline Anacardium occidentale & 3 & & \\
\hline Artocarpus heterophyllus & 1 & & 3 \\
\hline Chrysobalanus icaco & & 6 & 18 \\
\hline Cinnamomum verum & 16 & 134 & 45 \\
\hline Hevea brasiliensis & & 1 & \\
\hline Hydnocarpus pentandra & & & 8 \\
\hline Memecylon floribundum & 1496 & 7 & 3 \\
\hline Pandanus utilis & & & 1 \\
\hline Paraserianthes falcataria & & 10 & 2 \\
\hline Psidium littorale & & 4 & \\
\hline Sandoricum koetjape & & & 1 \\
\hline Spathodea campanulata & & & 1 \\
\hline Tabebuia pallida & 3 & 2 & \\
\hline \multicolumn{4}{|l|}{ Indigenous } \\
\hline Calophyllum inophyllum & 8 & & \\
\hline Cerbera manghas & & 7 & \\
\hline Cocos nucifera & 1 & & \\
\hline Dracaena reflexa & & 2 & \\
\hline Pyrostria bibracteata & & & 2 \\
\hline \multicolumn{4}{|l|}{ Endemic } \\
\hline Nephrosperma vanhoutteanum & & & 3 \\
\hline Phoenicophorium borsigianum & & 5 & 4 \\
\hline Roscheria melanochaetes & & & 3 \\
\hline
\end{tabular}


dense cinnamon canopy shading out other species. The inability of $M$. floribundum to dominate closed canopy forest indicates that it will exclude other plants only where the light intensity at ground level is high, i.e. on steep ridges and on very rocky or exposed areas. While most forests retain dense tree canopies M. floribundum will probably spread only slowly.

$M$. floribundum-dominated areas have a very low diversity of plant species. Detailed data for Seychelles are not available but a brief comparison shows that even degraded forests dominated by cinnamon support twice as many tree species as equivalent areas of $M$. floribundum (13 species, of which one was indigenous, in $175 \mathrm{sq}$ m compared with seven, of which four species were indigenous or endemic) (cinnamon forest data collected at Le Niol and Trois Freres, Mahe). The species recorded are listed in Table 1.

The domination of $M$. floribundum reduces the abundance of invertebrates occurring in the vegetation due to the almost complete absence of invertebrate species feeding on this plant in Seychelles. Very few leaves show signs of being attacked by insects and no phytophagous species were observed on any of the plants studied. A scale insect is abundant on the fruiting stems where it is tended by the introduced ant Anoplolepsis longipes. The leaf litter on the ground is thin and dry, and animal life is notably scarce, with the exception of A. longipes colonies and a terrestrial amphipod that is abundant in degraded habitats.

Snails were recorded as an easily identified indicator of environmental quality. In the $M$. floribundum habitat no snails were recorded in quadrats. The only snails located were the introduced Achatina fulica, Gonaxis quadrilateris and Subulina octona. The paucity of snails and the absence of indigenous species compared with their relative abundance in degraded secondary forest (an equal area of such habitat was studied at Le Niol where snail density was recorded at $3 / \mathrm{sq} \mathrm{m}$, of which 81 per cent were indigenous) indicates that the consequences of replacement of natural, or even cinnamon-dominated, forest has drastic consequences for native plants and animals. Data obtained at a variety of localities on Mahe are compared in Table 2, showing that native forest has a greater density of indigenous snail species, and that $M$. floribundum-dominated habitat has the lowest density of snails of any forested habitat on the island. Further expansion of this habitat is clearly undesirable. In this light it is particularly unfortunate that predation of $M$. floribundum by invertebrates in Seychelles is insignificant.

\section{Clidemia hirta}

The threat posed by Clidemia hirta in Seychelles was identified in 1990 by the Oxford University Silhouette Expedition (1990) This Central-South American species was first recorded on Silhouette in 1987 (Robertson, 1989). There are no precise data on the introduction or spread until 1990. In April 1990 a large C. hirta-dominated area was noted at Mon Plaisir near Mt Pot a Eau; some isolated plants were also present at Jardin Marron at about $300 \mathrm{~m}$ above sea level. The expedition subsequently noticed small plants below $200 \mathrm{~m}$ in July-September. Clidemia hirta was found to be common in the undergrowth

Table 2. Densities of snails recorded in quadrats in various habitats on Mahe

\begin{tabular}{lllll}
\hline Site & $\begin{array}{l}\text { Area surveyed } \\
(\mathrm{sq} \mathrm{m})\end{array}$ & Habitat & $\begin{array}{l}\text { Snail density } \\
\text { (no. per sq m) }\end{array}$ & \% indigenous \\
\hline Beau Vallon & 200 & M. floribundum & 0 & - \\
Le Niol & 175 & Native \& introduced & 3.0 & 81 \\
Trois Freres & 250 & C. verum forest & 2.8 & 29.8 \\
Congo Rouge & 250 & Native mist forest & 2.7 & 100 \\
Morne Blanc & 250 & Native forest & 1.5 & 100 \\
Copolia & 250 & Native forest & 3.3 & 93.9 \\
\hline
\end{tabular}


of most high forest areas, dominating some $2000 \mathrm{sq} \mathrm{m}$ at Mon Plaisir, parts of Mt Dauban and Mare aux Cochons. There were other areas where $C$. hirta was very abundant. An indication of its abundance was provided by the vegetation studies carried out in Pisonia sechellarum forest where C. hirta was not noticeably abundant but was still recorded in 45 out of 654 -sq-m quadrats. During a visit to Silhouette in August 1991 the presence of $C$. hirta was noted over a large part of the island (see Figure 2).

By August 1991 C. hirta had spread down to sea level. The area at Mon Plaisir had become denser and was now 2-3 m high. Like $M$. floribundum, C. hirta forms a dense canopy some 2 $\mathrm{m}$ above ground, below which there is little foliage. This allows a clear view under the canopy. C. hirta areas have few ground plants; some palm seedlings and occasional Phaius tetragonus ground orchids were noted. Growing in the $C$. hirta at Mon Plaisir were Begonia sechellensis, Rubus rosifolius and an indigenous member of the Melastomataceae, Melastoma malabathricum. As yet no quantitative studies have been undertaken in these areas but the surrounding natural habitat clearly has a much higher diversity of plant species.

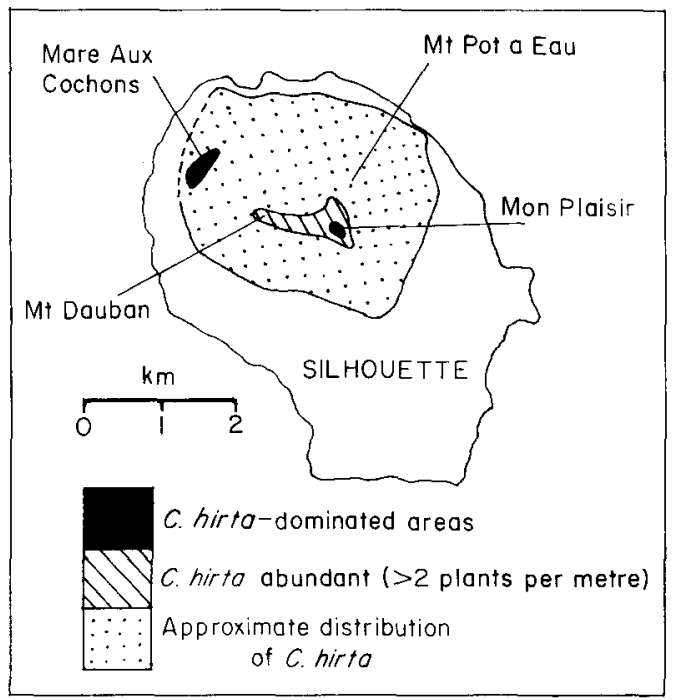

Figure 2. Distribution of Clidemia hirta on Silhouette by July 1991, showing the general distribution of the species and the areas it dominates, based on field surveys.
It appears that on Silhouette C. hirta will grow profusely only in very damp areas (the high ridge of the island and at Mare aux Cochons). The dry south of the island is virtually free of $C$. hirta; the coastal plants suffer severe wind-burn and, although these small individuals flower and set seed, the flowers are very small and the number of seeds set very low. Within the damp areas it replaces the natural vegetation by growing in gaps created by fallen trees, on land slips or as epiphytes. This is unfortunately facilitated by the steep rocky terrain of the island, which results in a high light intensity in most areas of forest.

At Mare aux Cochons it has replaced an area of Melastoma malabathricum and Gynura sechellarum described by Scott (Scott, 1910); very few plants of either of these species occur there today. Replacement of indigenous plants by this species, which is rarely eaten by insects, may further reduce insect abundance in this drained marsh area. Drainage and degradation of marshes in Seychelles may have contributed to the decline of the endangered Seychelles sheath-tailed bat Coleura seychellensis and the endangered butterflies Eupolea mitra and Phalanta philiberti, which used to be common at Mare aux Cochons (Scott, 1910).

Very few $C$. hirta leaves show signs of insect feeding and this was the only shrub for which no lepidopteran predators were recorded by the Oxford University Silhouette Expedition in the Pisonia sechellarum forest. Its fruits have been observed being eaten by bulbuls Hypsipetes crassirostris, which may act as the main dispersal agents in Seychelles.

Due to the very high numbers of seeds per fruit and consequent efficient dispersal of $C$. hirta, this species may be a more serious threat to the ecology of Seychelles than M. floribundum (C. hirta has up to 300 seeds per fruit compared with one in $M$. floribundum). This threat and possible control measures were discussed in the report of the Oxford University Silhouette Expedition (1990). This discussion concluded that physical removal and burning of the plants was advisable. However, it now seems that the $C$. hirta invasion is more advanced than was initially realized. 
It is probably no longer possible to eradicate the species from Seychelles by physical means. Various biological control agents have been used in the Pacific in attempts to control $C$. hirta: these have had mixed results. While control has been reported in a few cases, the persistence of the problem suggests that the reports of success have been premature. Most attempts at control have failed due in part to the control agents suffering very high rates of predation and parasitism from the established invertebrate fauna. Due to the large number of brief reports of control attempts for this species and the dispersion of the published accounts, detailed consideration of control measures is beyond the scope of the present paper. It is worth noting that any attempt at this means of control in Seychelles would probably encounter the usual problems of biological control (Howarth, 1991), with the additional complication of further endangering the reduced populations of Melastoma malabathricum, which used to be an important constituent of natural habitats on Silhouette. It has been suggested that careful tests for hostspecificity prior to release would eliminate this possibility. However, the cumulated evidence of many years of biological control programmes suggests that it is no longer possible to believe that such solutions are reliable, given the possibilities of dietary switching and local phytochemical changes that may induce such switching (Howarth, 1991). Although cutting and uprooting the main areas affected would be labour intensive and would require continuous management this is probably the most reliable means of exercising some control of C. hirta without threatening already reduced populations of rare plants. In some areas of Silhouette this form of management would be unacceptably destructive (principally in the extremely fragile habitats of the Mt Dauban ridge and the boulder fields of the valleys around Mt Dauban and Mt Pot a Eau).
Because these areas should be visited only very infrequently $C$. hirta control would consequently have to be limited and infrequent. If carried out carefully and thoroughly, effective control may be possible without excessive damage to these vulnerable habitats.

It should be noted that the control of $C$. hirta is of particular importance because it threatens the habitats of Silhouette. As mentioned above this island supports important populations of rare plants endemic to Seychelles and several Silhouette endemics with limited ranges. The fragility and composition of the habitats on Silhouette means that this is both the most ecologically sensitive and, in terms of biodiversity and state of preservation, most important island in Seychelles.

\section{References}

Friedmann, F. 1991. The threatened plants of the flora of the Seychelles and their conservation. In Tropical Botanic Gardens, Their Role in Conservation and Development (eds. V. H. Heywood and P. S. Wyse Jackson). Academic Press, London.

Howarth, F.G. 1991. Environmental impacts of biological control. Ann. Rev. Entomol. 1991. 36, 485-509.

Nevill, G. 1869. Additional notes on the land-shells of the Seychelles Islands. Proc. Zool. Soc., Lond. 1869. 5, 61-66.

Oxford University Silhouette Expedition, 1990. Final Report. 131 pp. Mimeo.

Procter, J. 1984. Vegetation of the granitic islands of the Seychelles, and Floristic of the granitic islands of the Seychelles. In Biogeography and Ecology of the Seychelle Islands (ed. D. R. Stoddart). Junk, Netherlands.

Robertson, S.A. 1989. Flowering Plants of Seychelles. Royal Botanic Gardens, Kew.

Scott, H. 1910. Eight months entomological collecting in the Seychelle Islands. Trans. Linn. Soc., Lond. (Zool.), 14, 24-39.

Justin Gerlach, Department of Zoology, South Parks Road, Oxford OX1 3PS, UK. 